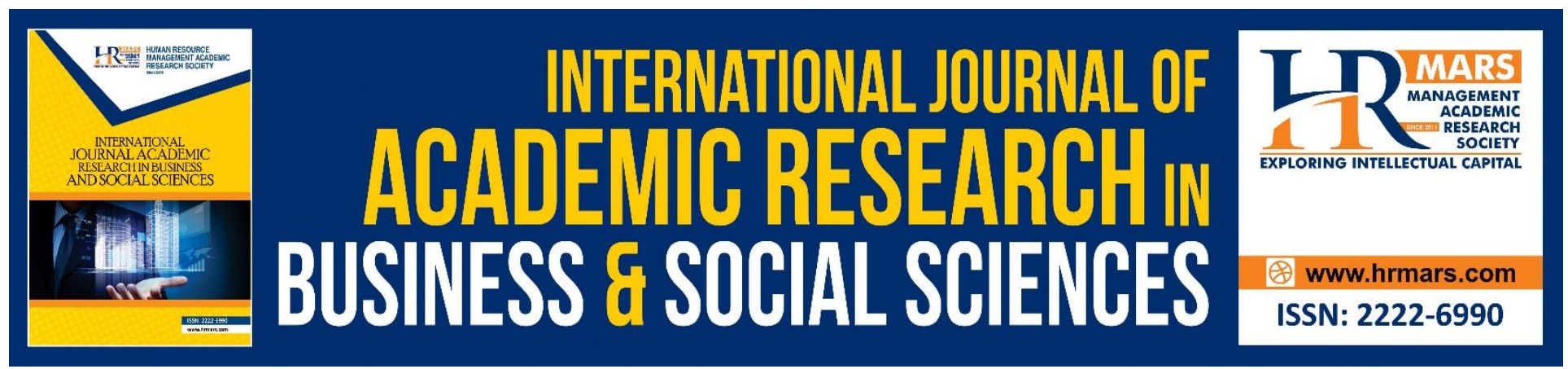

\title{
Adult Education in Johor Before Independence
}

\section{Nur Farhana Mohd Kosni, Khairi Ariffin}

To Link this Article: http://dx.doi.org/10.6007/IJARBSS/v10-i9/7860

DOI:10.6007/IJARBSS/v10-i9/7860

Received: 10 July 2020, Revised: 27 July 2020, Accepted: 14 August 2020

Published Online: 24 September 2020

In-Text Citation: (Kosni, \& Ariffin, 2020)

To Cite this Article: Kosni, N. F. M., \& Ariffin, K. (2020). Adult Education in Johor Before Independence. International Journal of Academic Research in Business and Social Sciences. 10(9), 726-735.

\section{Copyright: (C) 2020 The Author(s)}

Published by Human Resource Management Academic Research Society (www.hrmars.com)

This article is published under the Creative Commons Attribution (CC BY 4.0) license. Anyone may reproduce, distribute, translate and create derivative works of this article (for both commercial and non-commercial purposes), subject to full attribution to the original publication and authors. The full terms of this license may be seen

at: http://creativecommons.org/licences/by/4.0/legalcode

\section{Vol. 10, No. 9, 2020, Pg. 726 - 735}

Full Terms \& Conditions of access and use can be found at http://hrmars.com/index.php/pages/detail/publication-ethics 


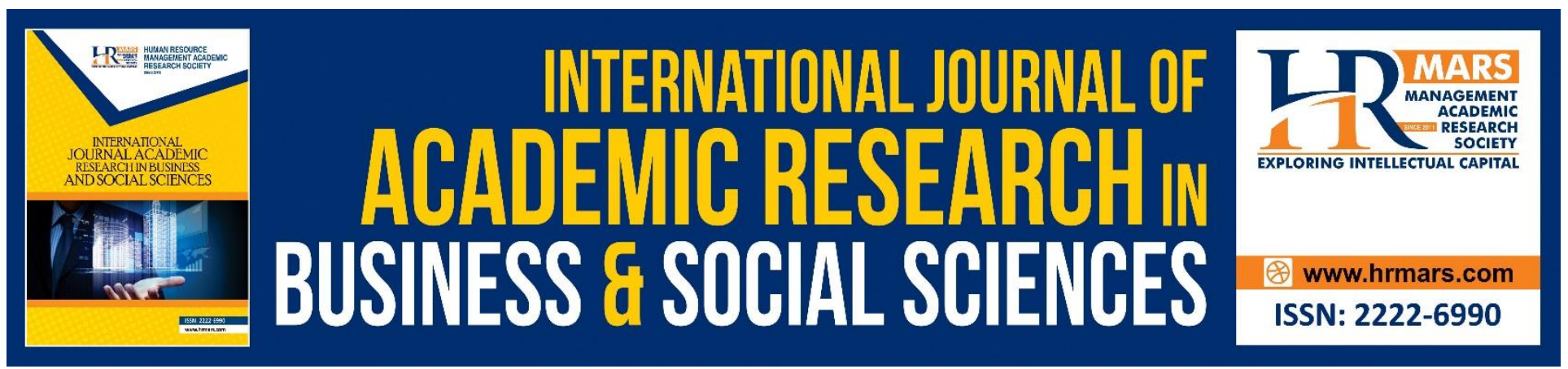

\title{
Adult Education in Johor Before Independence
}

\author{
Nur Farhana Mohd Kosni, Khairi Ariffin
}

Faculty of Human Deveploment, Universiti Pendidikan Sultan Idris, 35900 Tanjong Malim, Perak.

\begin{abstract}
This article is related to Adult Education among the Malays in Johor in the days before independence, which is around 1950 to 1956 . The British colonial upbringing the pattern of education in Johor changed the structure of education that was initially traditional and more religious based. However, this cycle began to change slowly in the consciousness of the Malays towards education in the form of socialization in order to achieve better social mobility, not only to individuals but also to the entire community. Adult Education was first introduced in Johor as the community began to take the concept of wide and global education. The production of this article is to see the development of Adult Education in Johor and the impact of the community socialization among adults in Johor. This study uses qualitative methods by analyzing data and sources based on references in archives and libraries. This study was prepared and evaluated based on references to the primary and secondary sources from the Arkib Negara Malaysia, Perpustakaan Negara Malaysia and Perpustakaan Tunku Bainun Universiti Pendidikan Sultan Idris. The results showed that the Malays welcomed the Adult Education classes as an alternative to increasing the knowledge, skills and indirectly improve the standard of living when they venture into the job better than before. Awareness of the importance of this knowledge and the Malays makes adults successfully forming a cycle life of more advanced and open. In conclusion, this article shows that although formerly Malays than Islam considers education as secular education that must be opposed, but they began to realize the importance of knowledge that will help them grow and succeed in pursuing modernization.
\end{abstract}

Keywords: Adult Education, Traditional, Independence, Knowledge, Socialization.

\section{Introduction}

“.....pendidikan merupakan wahana atau alat penting kepada individu dan masyarakat bagi meningkatkan mobiliti sosial masing-masing. Berbeza sama sekali pada zaman pra sejarah, zaman feudal dan pasca-feudal yang mana mobiliti sosial ditandai oleh bangsa, ras, keturunan dan status sosial yang dimiliki. Hal semacam ini menggambarkan susana dan latarbelakang 'feudalisme' dan 'early capitalisme' samada di negara-negara mundur seperti India mahupun negara maju seperti Britain. Pendidikan suatu masa dahulu bersifat 'prestigous' dan elitis telah berubah arah kepada berbentuk massa. Pendidikan bukan lagi 'lambang' bagi kelas dan golongan tertentu seperti mana yang berlaku di Tanah Melayu pada awal tahun 1920-an hingga terungkapnya Penyata Razak pada 1961."(Azhar, 2018) 
INTERNATIONAL JOURNAL OF ACADEMIC RESEARCH IN BUSINESS AND SOCIAL SCIENCES Vol. 10, No. 9, 2020, E-ISSN: 2222-6990 @ 2020 HRMARS

Adult learners are those who are interested in learning and positive self-esteem (Junoh, 2006: 5). Adult learning refers to the process by which individuals seek to change or improve their knowledge, values, skills or strategies (Azman, 2016: 67). Illiterates are usually identified from villages or areas that are hard to get access to education. There are many factors that make up the Adult Education class in Johor. It tends to the desire to improve social mobility, self-development, career and social. For the Malays, the knowledge is very important in ensuring a person to get out of the backwardness live in villages that are only seeking a survival job.

“........pendidikan dewasa sebagai pendidikan untuk orang dewasa lelaki dan perempuan bagi memenuhi keperluan dan minat yang pelbagai menurut tahap kebolehan dan kefahaman dan bagi mengisi perubahan peranan dan tanggungjawab dalam kehidupan." (Azhar etl., 2018: 103)

Adult Education also indicates that adults are still capable of receiving education even though they do not have the opportunity to gain it in young age. Adult education is also considered as an intellectual jihad of Muslim Malays (Khair etl., 2013: 18-21).

"Menyentuh tentang teori pembelajaran, banyak pendapat menyatakan mengapa seseorang dewasa belajar. Seseorang dewasa dikatakan bersedia untuk belajar apabila mereka berhadapan dengan situasi yang rumit, yang menuntut agar mereka belajar bagi memperbaiki kualiti hasil kerja atau peringkat kehidupan seharian. Ini termasuk individu sama ada seorang pekerja, suami atau isteri, ibu atau bapa, seorang ketua sesebuah organisasi atau pekerja dalam organisasi. Pelajar dewasa lebih suka pembelajaran yang berkaitan dengan pengalaman hidupnya dan ia akan menjadi lebih bermakna apabila pembelajaran itu boleh diaplikasikan dalam menyelesaikan sebarang masalah harian atau masalah-masalah di tempat kerja" (Ismail etl., 2015: 2)

Education is an ongoing process that begins at an early age. In this process, all natural abilities are born in accordance with the natural will and rules. Society and education are moving along as education is the mold of human form (Jamaluddin, 2011: 34). Process education in the form of socialization among the Malay community in Johor has been occurring since childhood yet. They have experienced the development of a more traditional and more religious-based early education. The concept of education before British colonial in Johor is said to be not formal, but rather a process of socialization which contain process guidance in various forms of abilities, the process of formation and character and also the process of familiarizing themselves with the essence of cultural heritage (Saadon etl., 2016: 80).

\section{Problem Statement}

Higher illiteracy rate among the Malays before independence. It is driven by the narrowness of thinking of the Malays to be more open and formal education, especially those who still live in the villages and their customs and traditional culture. To curb the problem of illiteracy among adults Malays in Johor, the colonial government has introduced an education system that is called Adult Education (Superintendent Of Education 7a/51. Adult Education). In Johor, Adult Education classes already been introduced since 1950. This education clearly aimed in combating illiteracy among adult Malays in Johor. Due to the colonial government only emphasize education for children Malays, the 
INTERNATIONAL JOURNAL OF ACADEMIC RESEARCH IN BUSINESS AND SOCIAL SCIENCES Vol. 10, No. 9, 2020, E-ISSN: 2222-6990 @ 2020 HRMARS

whole community of adults, especially those living in villages and rural areas less exposed with skills and knowledge.

\section{Methodology}

In preparing this article, the researcher has used qualitative methods of analyzing documents and manuscripts. The researcher source consisting of primary sources and secondary sources. The primary sources obtained from Arkib Negara Johor Bharu such as file Adult Education and Education Report in Johore as well as anything related to Adult Education in Johor. The resources obtained were analyzed and interpreted for the writing of this study. Historical interpretation using a hermeneuetic approach, which is to interpret historical facts with the help of documents obtained. Researchers also analyzed data based on secondary sources related to previous studies. This resources has been obtained from libraries such as Perpustakaan Tunku Bainun Universiti Pendidikan Sultan Idris, Perpustakaan Negeri Johor and Perpustakaan Negara to get books, magazines and previous studies related to the subject made that is Adult Education in Johor.

\section{Results}

Adult Education Classes are recommended to take 120 hours of courses in English and 40 other languages recognized hours for a period of three terms with a two month leave every year (Superintendent Of Education 7a/51. Adult Education). Adult Education has received funding from the colonial government in its implementation. This indirectly indicates that the government is committed and intensity to achieve the Adult Education class objective of eradicate illiteracy among adults.

Students are assigned into three categories reader : First Reader, Second Reader and Third reader. First Readers must complete the syllabus of Eradicate Illiteracy set for 20 hours. This means they need to complete their study of the textbook in a set time period. While the Second Reader has to complete the three part Hussien Anak Laki - Laki syllabus, the first section is 9 hours, the second and third sections need for 5 hours. The Third Reader completes a three part General Knowledge syllabus, each of which need 10 hours (Superintendent Of Education 7a/51. Adult Education).

"It is considered that in respect of the three Malay Readers the Student should give sufficiant time to digest the First Reader (Membasmi Buta Huruf) and a reasonable food number of hours for the Second Reader (Hussein Laki-laki Yang Bijak) and a proportionate period for the Third Reader (Pengetahuan Am). It is obious that, in fairness to the student, a good and sufficient grounding of the First Reader should be given if he is to be expected to make good and sound progress in respect of the other two subsequent readers." (Superintendent Of Education 7a/51. Adult Education).

A longer period given to student First Readers is to make sure they really dominate the basic syllabus, before continuing to the next lesson. Mastery of basic syllabus enables them to understand higher level syllabus and ensure the development of learning goes well (Superintendent Of Education 7a/51. Adult Education). 
INTERNATIONAL JOURNAL OF ACADEMIC RESEARCH IN BUSINESS AND SOCIAL SCIENCES Vol. 10, No. 9, 2020, E-ISSN: 2222-6990 @ 2020 HRMARS

Table 1: List of Names and Villages in the Classes of the Illiteracy Senggarang Team in 1953

\begin{tabular}{|c|l|}
\hline Bil & \multicolumn{1}{|c|}{ Names of Villages } \\
\hline $\mathbf{1}$ & Kampung Sungai Suluh \\
\hline $\mathbf{2}$ & Kampung Koris \\
\hline $\mathbf{3}$ & Kampung Sri Molek \\
\hline $\mathbf{4}$ & Kampung Senggarang \\
\hline $\mathbf{5}$ & Kampung Parit Kadir \\
\hline $\mathbf{6}$ & Kampung Baharu \\
\hline $\mathbf{7}$ & Kampung Punggur \\
\hline $\mathbf{8}$ & Kampung Sri Perpat \\
\hline $\mathbf{9}$ & Kampung Rejosari \\
\hline $\mathbf{1 0}$ & Kampung Sungai Tongkang \\
\hline
\end{tabular}

(Superintendent Of Education 7a/51. Adult Education)

According to Table 1, there are 10 villages that carry out Adult Education in Senggarang, Johor, that is Kampung Sungai Suluh, Kampung Koris, Kampung Sri Molek, Kampung Senggarang, Kampung Parit Kadir, Kampung Baharu, Kampung Punggur, Kampung Sri Perpat, Kampung Rejosari dan Kampung Sungai Tongkang.

\section{Financial Assistance}

Like other schools, an Adult Education class in Johor is also no exception to receive financial assistance from the colonial government. The fund is provided through the Financial Assistance Scheme, but it have a conditions that must be obeyed before it is provided (Superintendent Of Education 7a/51. Adult Education. 'Notes on Complication Of The Form For Consolidated Quarterly Returns'). The school must fill out a form that is submitted with the annual statements to the Department of Education. 
INTERNATIONAL JOURNAL OF ACADEMIC RESEARCH IN BUSINESS AND SOCIAL SCIENCES Vol. 10, No. 9, 2020, E-ISSN: 2222-6990 @ 2020 HRMARS

\section{Table 2: Review of Financial Assistance Scheme for Associations Adult Education Classes}

(Superintendent of education 7a/51. Adult Education)

1 Classes eligible for assistance

Subject to the conditions set out below Government will give financial assistance toward teaching cost of

a) Literacy and language classes in English, Malay, Chinese and Tamil

b) Civics classes

2 Scale of assistance

The scale of assistance is as follows:

a) Literacy and language classes, English, Malay, Chinese and Tamil

Municipal and Town Board areas $\quad 75 \%$

Rural areas $\quad 100 \%$

b) Civics classes all areas $\quad 100 \%$

3 Conditions

i) Classes shall consist of not more than 120 one-hour periods during any year; and shall meet not more than 3 times in any week.

ii) The recognized fee for instructors shall be $4 \$$ per hour.

iii) The minimum and maximum enrolments shall be as follows:

a) Municipal and Town Board Areas : Minimum of 20 per class

Minimum of 30 per class

which may with permission of the local Department of Education be increased to 35 per class

b) Rural Areas

iv) In cases where attendance falls below $50 \%$ of the enrolment during successive meetings the class shall cease to be eligible for grant.

v) The Local Department of Education shall be satisfied as to the qualifications of teachers, which need not necessarily be academic.

vi) Fees may be charged for attendance at classes and may be used for the administrative and running expenses of the local Associations, and maintenance of buildings and class-rooms used by them.

4 This revised Scheme of Assistance is effective from $1^{\text {st }}$ May, 1953.

Based on the table above, the financial assistance scheme was introduced to help finance adult classes have been reviewed. Among the classes that receive assistance from the government is Literature Classes and Languages in English, Bahasa Melayu, Chinese, Tamil and Civics classes. Literature class located in urban areas received 75 percent support, while rural areas receive as much as 100 percent, as well as Civics classes that receive assistance of 100 percent. However, there are 
INTERNATIONAL JOURNAL OF ACADEMIC RESEARCH IN BUSINESS AND SOCIAL SCIENCES Vol. 10, No. 9, 2020, E-ISSN: 2222-6990 @ 2020 HRMARS

conditions that must be obeyed, such as classes to be held not more than 120 hours in a year and to be met not more than 3 times in any given week.

The minimum and maximum registration for municipal and urban areas shall be a minimum of twenty people per class or a minimum of thirty people per class. It may also be increased to thirtyfive people per class with the permission of local Education Department. For rural areas, the minimum limit is fifteen people per class and a maximum of thirty-five per class. In some cases when attendance drops below 50 percent of class registrations four times in a row, that class is disqualified for financial assistance. Local Education Departments should be satisfied with the qualifications of teachers, who do not necessarily have academic qualifications. This reviewed of Aid Scheme is effective from May 1, 1953 (Superintendent of education 7a/51. Adult Education. 'Editorial').

\section{Time table}

The time of study is three times a week for 1 hour and 30 minutes at a time. Classes will be held after Friday prayers from 2 to 3.30 pm, every Tuesday night from 8 to $9.30 \mathrm{pm}$ and every Thursday night from 8 to 9.30 pm. (Superintendent Of Education 7a/51. Adult Education. 'Opening the Literature Class')

Table 3: Adult Classes in Batu Pahat, Johor

\begin{tabular}{|c|c|c|c|c|}
\hline $\begin{array}{l}\text { Num. of } \\
\text { Students }\end{array}$ & Area & Time & Teachers & $\begin{array}{l}\text { Start Class } \\
\text { Dated }\end{array}$ \\
\hline 27 (Lelaki) & $\begin{array}{c}\text { Sekolah Melayu } \\
\text { Machap }\end{array}$ & $\begin{array}{c}\text { 3.30-5.00 ( } 3 \text { hari } \\
\text { seminggu) }\end{array}$ & T.O'Wise & 1.5 .52 \\
\hline $\begin{array}{c}20 \\
\text { (Wanita) }\end{array}$ & $\begin{array}{l}\text { Sekolah Melayu } \\
\text { Bandar Rahmat }\end{array}$ & $\begin{array}{c}\text { 3.30-5.00 ( } 3 \text { hari } \\
\text { seminggu) }\end{array}$ & Naib Kadhi & 1950 \\
\hline 20 (Lelaki) & $\begin{array}{l}\text { Sekolah Melayu } \\
\text { Parit Sulong }\end{array}$ & 2.00-4.00 (Jumaat) & Lepasan SITC & 14.8 .52 \\
\hline 34 (Lelaki) & $\begin{array}{l}\text { Sekolah Melayu } \\
\text { Sri Maimon }\end{array}$ & $\begin{array}{l}2.00-4.00 \text { ( } 3 \text { hari } \\
\text { seminggu) }\end{array}$ & T.O'Wise & 14.8 .52 \\
\hline 15 (Lelaki) & $\begin{array}{c}\text { Persatuan Guru } \\
\text { Melayu BP }\end{array}$ & $\begin{array}{c}7.00-8.30 \text { ( } 3 \text { hari } \\
\text { seminggu) }\end{array}$ & $\begin{array}{l}\text { Guru Penggerak } \\
\text { Sekolah Inggeris }\end{array}$ & 1951 \\
\hline 33 (Lelaki) & $\begin{array}{c}\text { Sekolah Melayu } \\
\text { Senggarang }\end{array}$ & $\begin{array}{c}3.00-4.30 \text { ( } 3 \text { hari } \\
\text { seminggu) }\end{array}$ & T.E.V.S.BP & 14.8 .52 \\
\hline 30 (Lelaki) & $\begin{array}{l}\text { Sekolah Melayu } \\
\text { Pintas Puding }\end{array}$ & $\begin{array}{c}3.30-5.30 \text { ( } 3 \text { hari } \\
\text { seminggu) }\end{array}$ & T.E.V.S.BP & 14.8 .52 \\
\hline 15 (Lelaki) & $\begin{array}{l}\text { Sekolah Melayu } \\
\text { Sri Gading }\end{array}$ & $\begin{array}{c}3.30-5.30 \text { ( } 3 \text { hari } \\
\text { seminggu) }\end{array}$ & T.E.V.S.BP & 8.9 .51 \\
\hline 25 (Lelaki) & $\begin{array}{c}\text { Sekolah Melayu } \\
\text { Rengit }\end{array}$ & $\begin{array}{c}\text { 3.00-5.00 ( } 3 \text { hari } \\
\text { seminggu) }\end{array}$ & T.E.V.S.BP & 4.8 .51 \\
\hline 40 (Lelaki) & $\begin{array}{c}\text { Sekolah Melayu } \\
\text { Perempuan } \\
\text { Peserai } \\
\end{array}$ & $\begin{array}{l}7.30-10.30 \text { ( } 3 \text { hari } \\
\text { seminggu) }\end{array}$ & Bekas Guru & 7.5 .52 \\
\hline 28 (Lelaki) & Bagan & $\begin{array}{c}3.00-5.00 \text { ( } 3 \text { hari } \\
\text { seminggu) }\end{array}$ & T.E.V.S.BP & 3.9 .51 \\
\hline 30 (Lelaki) & $\begin{array}{c}\text { Sekolah Melayu } \\
\text { Kluang }\end{array}$ & $\begin{array}{l}\text { 5.00-6.00 (3 hari } \\
\text { seminggu) }\end{array}$ & $\begin{array}{c}\text { Kakitangan } \\
\text { Kerajaan }\end{array}$ & 9.52 \\
\hline
\end{tabular}

(Superintendent Of Education 7a/51. Adult Education. Ref.(27) in I of M.S.B.P 21/52) 
INTERNATIONAL JOURNAL OF ACADEMIC RESEARCH IN BUSINESS AND SOCIAL SCIENCES Vol. 10, No. 9, 2020, E-ISSN: 2222-6990 @ 2020 HRMARS

Based on Table 3, there are 12 adult classes opened around Batu Pahat, Johor. Most of Adult Education classes open in the buildings of Malay schools. Adult Education Classes first in Johor was opened in 1950 at Sekolah Melayu Bandar Rahmat and Naib Kadhi as teacher and students accompanied by 20 female students. In 1951, 4 of Adult Education Classes were opened and carried out at the office of Malay Teachers Association Batu Pahat, Sekolah Melayu Sri Gading, Sekolah Melayu Rengit and Bagan. After that, in 1952, 7 other class opened at Sekolah Melayu Machap, Sekolah Melayu Parit Sulong, Sekolah Melayu Sri Maimon, Sekolah Melayu Senggarang, Sekolah Melayu Pintas Puding, Sekolah Melayu Perempuan Peserai and Sekolah Melayu Kluang. Classes are usually attended by 20 to 40 students.

Most students are male, only one class is female adult. The class are held three times a week and class time is set by together consent. The class will run for 1 hour and 30 minutes for up to 2 hours a day. The teachers to teach in adult classes are those who are qualified and trusted. They consist of Malay school teacher, vice Kadi, former teachers, government employees and graduates of the Kolej Latihan Sultan Idris (Superintendent Of Education 7a / 51. Adult Education. Ref. (27) in the first of M.S.B.P 21/52).

\section{Teachers}

Malay school teachers are not responsible for teaching and educating children in Malay schools only, but also serve as instructors in the class of Adult Education. On January 30, 1956, a letter was sent by a female teacher named Ungku Kalthom Binti Othman to Nadzir Malay schools in Batu Pahat. The letter contained her request for an allowance or salary for her services as a part-time Adult Education instructor for mothers in Kampung Parit Ya'ani, Johor. (Superintendent Of Education 7a/51. Adult Education)

"Adalah saya Ungku Kalthom Bt Othman, bekas murid sekolah perempuan Melayu Bandar Tinggi Batu Pahat dengan hormat-nya memaklumkan iaitu di-minta-lah dengan ihsan serta pertolongan tuan pada membawa permohonan saya ini kepada pihak yang berkuasa ia-itu saya memohon allowance mengajar sebagaimana yang di-keluarkan oleh Adult Education, kerana saya telah di-minta oleh kaum2 ibu kampong Parit Ya'ani, Mukim VI Batu Pahat, supaya mengajar di-kampong-nya dengan sa-orang penolong saya..... ."(Superintendent Of Education 7a/51. Adult Education)

He graduated standard VI in Malay School in 1952 and graduated from the training in Sekolah Rumah Tangga for three years with grade I in 1954. He applied for the grant of allowances for him and an assistant to teach in Bahasa Melayu, Cooking, Tailoring and Hand Works (Superintendent Of Education 7a/51. Adult Education). Teaching time was limited to 2 times a week on every Friday and Saturday starting at $1 \mathrm{pm}$ to $4 \mathrm{pm}$. The learning period will be 3 hours per session.

\section{Fees}

Related to the Adult Education fee, the Executive Committee of the Adult Education Association at its meeting on September 30, 1953 they decided to set a fee of $1.00 \$$ for the urban and $0.50 \$$ for the rural people. The decision of the meeting agreed that 50 percent of the fee income would be kept by the Branch Association and 50 percent would be handed over to the State of Association (Superintendent Of Education 7a / 51. Adult Education. 'Membuka Kelas Buta Huruf'). 
INTERNATIONAL JOURNAL OF ACADEMIC RESEARCH IN BUSINESS AND SOCIAL SCIENCES Vol. 10, No. 9, 2020, E-ISSN: 2222-6990 @ 2020 HRMARS

Payment of this fee in favor of the rural viewed. Indeed, Adult Education is focused on the rural population, the rural fees rate is lower than urban people indirectly encouraging them to participate in classes conducted in Malay schools.

\section{Conclusion}

The main objective of Adult Education in Johor is to eradicate illiteracy among adults. In addition, Adult Education is also conducted with the objective of providing adult learners with a better working environment in various sectors. Adult Education is an alternative education for adults who have never access to education. Adult Education emphasizes skill development and personal development importantly. By targeting the rural areas to be born as a knowledge society of knowledge, Adult Education in Johor is seen to achieve its goals. This success is measured by the growth of Adult Education over the years that shows a lot of class and the increasing number of students. Until the 1960s, efforts to distribute an Adult Education among the community become more active. With the knowledge gained from the Adult Education classes, adults, especially those living in rural areas began to explore opportunities for better jobs and do not focus on self-employment. It also made the society more knowledgeable and promote intellectual culture in the process of socialization.

\section{Corresponding Author}

Nur Farhana Mohd Kosni \& Khairi Ariffin

Faculty of Human Deveploment, Universiti Pendidikan Sultan Idris, 35900 Tanjong Malim, Perak.

Email: nurfarhana.mk@yahoo.com khairi.ariffin@fsk.upsi.edu.my

\section{References}

Azman, N. (2016). Pembelajaran Dewasa, dalam buku Panduan Amalan Pengajaran dan Pembelajaran Berkesan. Universiti Kebangsaan Malaysia.

Azrin, M. K. (2011). Sistem Pendidikan Di Malaysia: Dasar, Cabaran, Dan Pelaksanaan Ke Arah Perpaduan Nasional. Jurnal Pendidikan Sains Sosial Dan Kemanusiaan, SOSIOHUMANIKA 4(1), (33-45).

Hamid, M. A., Othman, M. F., Hassan, Z., \& Kassim, O. A. (2018). Pendidikan Bukan Formal (Pbf) Di Malaysia: Cabaran Dan Hala Tuju Wawasan 2020. Fakulti Pengurusan dan Pembangunan Sumber Manusia: Universiti Teknologi Malaysia.

Ismail, S.,Yusoff, M. F., Majid, M. A., Ahmad, S., \& Bakar, S. A. (2015). Pendidikan Dewasa: Kajian Di Masjid Al Azhar Kuis. Kolej Universiti Islam Antarabangsa Selangor.

Junoh, A. M. (2006). Atribut Pembelajaran Non-Formal Dalam Kalangan Orang Melayu Dewasa Di Malaysia. (Unpublished doctoral dissertation). Universiti Putra Malaysia.

Khair, Z.,Yusoff, R. M., \& Hamid, M. A. (2013). Pembelajaran Dewasa Sebagai Suatu Jihad Intelektual. PERINTIS E-Journal 3(1), (17-25).

Saadon, R., Ariffin, K., \& Saat, I. (2016). Perkembangan Pendidikan orang Melayu di Malaya Sebelum Kemunculan Western Type-Education. Jurnal Perspektif 8(2), (79-96).

Superintendent of Education 7a/51. Adult Education. 'Editorial'. 
INTERNATIONAL JOURNAL OF ACADEMIC RESEARCH IN BUSINESS AND SOCIAL SCIENCES Vol. 10, No. 9, 2020, E-ISSN: 2222-6990 @ 2020 HRMARS

Superintendent of Education 7a/51. Adult Education. 'Headquarters Administration Circular No. 12 of 1953'.

Superintendent Of Education 7a/51. Adult Education. 'Membuka Kelas Buta Huruf'.

Superintendent Of Education 7a/51. Adult Education. 'Notes on Complication of the form for Consolidated Quarterly Returns (A.E.A.4)'.

Superintendent of Education 7a/51. Adult Education. 'Penang Adult Education Association'..

Superintendent of education 7a/51. Adult Education. 'Revised Scheme of Financial Assistance to Adult Education Association Classes'. 